\title{
Pharmacological significance of biogenic amines in the lungs: histamine
}

\author{
DOMINGO M. AVIADO AND CHIRAVAT SADAVONGVIVAD*
}

Department of Pharmacology, School of Medicine, University of Pennsylvania, Philadelphia, Pennsylvania

\section{Summary}

1. Eight animal species were investigated for the histamine content of the lung and can be divided into two groups: the low-level group, ranging from 2 to 7 $\mu \mathrm{g} / \mathrm{g}$, consisting of the mouse, rat, guinea-pig and rabbit; and the high-level group, ranging from 12 to $35 \mu \mathrm{g} / \mathrm{g}$, consisting of the cat, dog, goat and human. In two species of the high-level group (cat and dog) the amount of histamine that elicited an increase in pulmonary resistance was one-fifth to one-tenth of the dose that elicited an increase in species of the low-level group (rat and rabbit). There is an inverse relationship between the content of histamine and the dose of histamine that produces a $25 \%$ increase in pulmonary resistance.

2. Anaphylaxis increases the histamine content of the lung of the rabbit but not of the lung of the guinea-pig. In both species, anaphylaxis is accompanied by an elevation of the concentration of 5-hydroxytryptamine in the lung, indicating the trapping of platelets in the lung.

3. The development of severe parasitaemia in the mouse inoculated with Plasmodium berghei is accompanied by an elevation of the histamine content of the lung. This increase appears to be part of the response of the lung to parasitaemia.

\section{Introduction}

The significance of histamine contained in the lung has attracted a considerable amount of attention since 1929, when the late Sir Henry Dale proposed that histamine is released and may mediate the symptoms seen in anaphylaxis (Dale, 1929). The first direct proof of the release of a substance with biological effects similar to those of histamine was supplied by Bartosch, Feldberg \& Nagel (1932), who added an antigen to the perfused lung of a sensitized guinea-pig. Their conclusion has been verified by spectrophotometric analysis for histamine contained in blood or perfusate from the lung in anaphylaxis (see references cited by Rocha $\mathrm{e}$ Silva, 1966).

On the other hand, the analysis of the lung tissue has not offered unequivocal evidence to support the release of histamine during anaphylaxis. A depletion in vivo of the histamine content of the lung in anaphylaxis has not been demon-

* Formerly Predoctoral Fellow of the Rockefeller Foundation. Present address: Department of Pharmacology, Faculty of Science, Mahidol University, Bangkok, Thailand. 
strated, although a reduction has been readily elicited by drugs that release histamine (see references cited by Mota, 1966), by corticosteroids (Carrillo \& Aviado, 1968), and by the induction of pulmonary oedema (Aviado, 1959), pulmonary embolism (Colebatch \& DeKock, 1963), and alveolar hypoxia (Aviado, Samanek \& Folle, 1966). On the contrary, during anaphylaxis in the rabbit, platelets are trapped in the lung so that there is an increase in the histamine and 5-hydroxytryptamine (5-HT) content of the lung (Waalkes \& Coburn, 1959). There is no information on hisstamine content of the lung during anaphylaxis in the guinea-pig, although 5-HT has been reported to be increased (Mariani \& Valzelli, 1958) or unchanged (Engelhardt \& Schwabe, 1960).

The availability of a technique for analysis of histamine, 5-HT, noradrenaline and dopamine in the lung (Sadavongvidad, 1970) offered an opportunity to reinvestigate the anaphylactic phenomenon in the guinea-pig and rabbit. In addition, malarial infection has been investigated in the mouse, because of the phagocytic cells that appear in the lung tissue as a result of the haemolysis of the parasitized erythrocytes (Sadavongvivad \& Aviado, 1969).

\section{Methods}

\section{Procedures in the guinea-pig}

The lungs were removed from the decapitated animal, which had been anaesthetized with diallylbarbituric acid $(60 \mathrm{mg} / \mathrm{kg})$ and urethane $(240 \mathrm{mg} / \mathrm{kg})$ intraperitoneally. Fifteen guinea-pigs, weighing from 300 to $350 \mathrm{~g}$, were divided into five groups of three animals per group. One group served as control ; a second group was sensitized $24 \mathrm{hr}$ previously by an intracardiac injection of rabbit serum containing antibodies against bovine serum albumin. On the day of the experiment, $1 \mathrm{ml}$ of saline was injected intracardially under ether anaesthesia and the lungs were removed for analysis of biogenic amines (see method reported by Sadavongvivad, 1970). A third group was also sensitized $24 \mathrm{hr}$ previously, and the antigen was administered $4 \mathrm{~min}$ before killing the animal. The remaining two groups were similarly sensitized and also received $5-\mathrm{HT}(30 \mathrm{mg} / \mathrm{kg})$ intraperitoneally daily for 6 days.

\section{Procedures in the rabbit}

Two series of experiments were carried out. Eight rabbits of both sexes, weighing about $1 \mathrm{~kg}$, were divided into two groups of four. One group remained as controls and those in the other group were sensitized to egg albumin solution, $10 \%$ in saline containing $0.5 \%$ phenol. Two $\mathrm{ml}$ of the albumin was injected intraperitoneally on the first day, and the same volume was injected subcutaneously daily for the next 3 days. After 6 weeks, the animals were anaesthetized with diallylbarbituric acid $(60 \mathrm{mg} / \mathrm{kg})$ and urethane $(240 \mathrm{mg} / \mathrm{kg})$ and decapitated before removal of the lungs.

In the second series of experiments, four rabbits which had been sensitized as in the first series were anaesthetized with diallylbarbituric acid and urethane, and the chest was opened under artificial ventilation. One lobe of the lung was removed, then a second lobe was removed $3 \mathrm{~min}$ after, and a third lobe $5 \mathrm{~min}$ after an injection of the antigen ( $2 \mathrm{ml}$ of $10 \%$ egg albumin) into the left ventricle. A sample was 
removed from each lobe before and after perfusion of the lobe with $100 \mathrm{ml}$ saline solution.

\section{Procedures in the rat, cat and dog}

The pulmonary responses to histamine were elicited in the rat, cat and dog, as well as in the rabbit (see preceding paragraph). The method for measurement of pulmonary resistance in the rat was as described by Sadavongvivad (1970). The method used in the larger animals was reported in an earlier publication (Klide \& Aviado, 1967). The animal was anaesthetized with chloralose $(100 \mu \mathrm{g} / \mathrm{kg})$ injected intravenously. In the dog the administration of chloralose was preceded by subcutaneous injection of morphine sulphate $(2 \mathrm{mg} / \mathrm{kg})$. An endotracheal tube was inserted and connected directly to a mesh screen Fleisch pneumotachograph, and the pressure difference across the screen was measured by a differential pressure transducer (Sanborn model 270). The signal from the transducer corresponded to air flow and was in turn integrated and recorded as tidal volume. Both flow and volume were recorded on a Sanborn Polyviso recorder. The pressure difference between the trachea and intrapleural space was measured by a second differential transducer (Sanborn 268B) and recorded on a third channel of the Polyviso recorder. To measure pulmonary resistance, the flow and pressure signals were displayed simultaneously on both axes of the oscilloscope screen to show a pressure-flow loop. Subsequently an amount of pressure proportional to volume was subtracted so that the loop was closed at zero flow. The slope of the line thus obtained corresponded to pulmonary resistance. The values for compliance were obtained similarly by displaying the P-V signals and subtracting pressure due to resistance.

\section{Procedures in the mouse}

Sixty-four Swiss strain mice, male, 4 weeks old, weighing about 20 to $25 \mathrm{~g}$, were divided into two groups. One group of thirty-two mice was used as control, and those in the other group of thirty-two mice were inoculated with a Plasmodium berghei strain that had become resistant to chloroquine, as described in an earlier report from this laboratory (Aviado, 1967). The mice were inoculated by intraperitoneal injection of 5 million parasites from an infected donor. From 10 to 13 days after inoculation, four control mice and four injected mice were killed each day. The lungs from the controls were pooled, as were the lungs of the malarial mice, and both pooled samples were analysed for their content of biogenic amines. The blood of the malarial mice was pooled and the percentage of the erythrocytes containing parasites was estimated by examination of blood smears after staining with Giemsa's stain.

\section{Results}

\section{Anaphylaxis in the guinea-pig}

The results obtained from the five groups of guinea-pigs are summarized in Table 1. The control group, which received saline intracardially, gave values for the concentrations of histamine and 5-HT in the lung tissue that were similar to those in the lungs of the sensitized group that received saline. The sensitized group that received an acute injection of the antigen showed no change in the histamine content of the lung. The content of 5-HT was increased in two out of three animals, how- 
ever, although the mean value was not significantly different from that of the sensitized group.

The group of animals that were sensitized, pretreated with 5-HT and in acute anaphylaxis, had a mean value for 5-HT that was two times larger than the group also pretreated but not in acute anaphylaxis. As in the earlier groups, these two groups did not show any change in the histamine concentration in the lung as a result of anaphylaxis.

\section{Anaphylaxis in the rabbit}

Five groups of four rabbits were used to investigate the effect of sensitization on the content of biogenic amines in the lung. The first two groups consisted of a control group and a group that was sensitized to egg albumin. On the day of the experiment, the rabbits were killed without receiving any antigen. There was no difference in the content of histamine, 5-HT, noradrenaline or dopamine in the lungs of the two groups respectively (Table 2). In the next group of four sensitized rabbits, samples of the lobe of the lung were removed for analysis before and after anaphylaxis was induced. The results summarized in Table 3 indicate an increase in both 5-HT and histamine content in the samples removed 3 and 5 min after anaphylaxis. The increase in content was also detectable in the samples from the lobe that had been perfused with saline to wash out the blood.

TABLE 1. Content of histamine and 5-HT in lung of guinea-pigs during anaphylaxis

\begin{tabular}{|c|c|c|c|}
\hline \multirow[b]{2}{*}{ Procedure } & \multirow{2}{*}{$\begin{array}{l}\text { No. of } \\
\text { animals }\end{array}$} & \multicolumn{2}{|c|}{ Mean \pm S.E.M. $\mu \mathrm{g} / \mathrm{g}$ lung } \\
\hline & & Histamine & 5-HT \\
\hline $\begin{array}{l}\text { Control } \\
\text { Sensitized }\end{array}$ & $\begin{array}{l}3 \\
3 \\
3\end{array}$ & $\begin{array}{l}7 \cdot 16 \pm 0.82 \\
7 \cdot 66 \pm 1 \cdot 45 \\
6.48 \pm 0.71\end{array}$ & $\begin{array}{l}0.23 \pm 0.02 \\
0.20 \pm 0.02 \\
0.29+0.07\end{array}$ \\
\hline $\begin{array}{l}\text { Sensitized, plus antigen } \\
\text { Sensitized, plus } \\
5-\mathrm{HT}(30 \mathrm{mg} / \mathrm{kg} \\
\text { daily for } 6 \text { days) }\end{array}$ & 3 & $6.49 \pm 0.81$ & $0.29 \pm 0.07$ \\
\hline $\begin{array}{l}\text { Sensitized, plus } \\
5-\mathrm{HT}(30 \mathrm{mg} / \mathrm{kg} \\
\text { daily for } 6 \text { days) plus } \\
\text { antigen }\end{array}$ & 3 & $5 \cdot 58 \pm 1 \cdot 10$ & $3 \cdot 40 \pm 0 \cdot 47^{*}$ \\
\hline
\end{tabular}

* $P<0.01$ compared with mean of sensitized animals receiving 5-HT but not antigen.

TABLE 2. Content of biogenic amines in lung of rabbits sensitized to egg albumin

\begin{tabular}{lccccc} 
& No. of & \multicolumn{4}{c}{ Mean \pm S.E.M. $\mu$ g/g lung } \\
\cline { 3 - 7 } Procedure & animals & Histamine & $5 . \mathrm{HT}$ & Noradrenaline & Dopamine \\
Not sensitized & 4 & $4.88 \pm 1.04$ & $6.78 \pm 1.04$ & $0.13 \pm 0.03$ & $0.25 \pm 0.02$ \\
Sensitized & 4 & $4.31 \pm 0.75$ & $5.40 \pm 0.80$ & $0.12 \pm 0.02$ & $0.23 \pm 0.03$
\end{tabular}

TABLE 3. Concentration of histamine and 5-HT in lung of rabbits during anaphylaxis

Mean \pm S.E.M. $\mu \mathrm{g} / \mathrm{g}$ lung

\begin{tabular}{|c|c|c|c|c|c|}
\hline & \multirow{3}{*}{$\begin{array}{l}\text { No. of } \\
\text { animals }\end{array}$} & \multirow{2}{*}{\multicolumn{2}{|c|}{ Histamine concentration }} & & \\
\hline \multirow[b]{2}{*}{ Procedure } & & & & \multicolumn{2}{|c|}{ 5-HT concentration } \\
\hline & & $\mu \mathrm{g} / \mathrm{g}$ wet & $\mu \mathrm{g} / \mathrm{g}$ dry & $\mu \mathrm{g}: \mathrm{g}$ wet & $\mu \mathrm{g} / \mathrm{g}$ dry \\
\hline 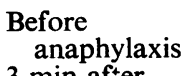 & 4 & $4 \cdot 42 \pm 1 \cdot 22$ & $15 \cdot 98 \pm 4 \cdot 32$ & $2 \cdot 31 \pm 0 \cdot 18$ & $8.45 \pm 1.41$ \\
\hline $\begin{array}{l}3 \text { min after } \\
\text { anaphylaxis }\end{array}$ & 4 & $6 \cdot 14^{*} \pm 1 \cdot 22$ & $21 \cdot 52 * \pm 3 \cdot 76$ & $8 \cdot 78^{*} \pm 2 \cdot 75$ & $31 \cdot 59 \dagger \pm 9 \cdot 32$ \\
\hline min arter & 4 & $8.84 \dagger \pm 1.56$ & $38 \cdot 66 \dagger \pm 7 \cdot 42$ & $10 \cdot 83 \ddagger \pm 2 \cdot 40$ & $47 \cdot 0_{+}^{+} \pm 10 \cdot 69$ \\
\hline
\end{tabular}

$* P<0 \cdot 1$ compared with mean values before anaphylaxis.

$\dagger P<0.05 . \quad \ddagger P<0.02$. 


\section{Responses to intravenous injections of histamine in the rat, rabbit, cat and dog}

The next step was to examine the content of histamine in four groups of animals, and to elicit the response to histamine. The results obtained from five rats, five rabbits, five cats and five dogs are summarized in Table 4 . In all species, the intravenous injection of histamine produced an elevation in pulmonary resistance. In the rat and rabbit, histamine caused a rise in blood pressure, but in the cat and dog, a fall. It is pertinent to point out that for the cat and dog, with lungs that contain concentrations of histamine higher than that in the lungs of the rat and the rabbit, the dose that would produce a $25 \%$ increase in resistance is one-fifth to one-tenth of the dose required to produce a similar effect in the other two species.

\section{Plasmodium berghei in the mouse}

In the last group of experiments, the lungs of control mice and of mice that had been inoculated with Plasmodium berghei (which is resistant to chloroquine) were compared. A group of four control mice and a group of four malarial mice were killed daily from 10 to 13 days after inoculation of the latter. The results summarized in Table 5 indicate the severe parasitaemia among the malarial groups. The same table shows a fall in the concentration of 5-HT and an increase in the concentration of histamine in the lung. As the malarial infection became severe, the elevated concentration of histamine in the lung was reduced, but the concentration of 5-HT remained low. There were no changes in the content of noradrenaline and dopamine.

\section{Discussion}

The results of analysis of histamine content in the lungs of six animal species reported above and in two additional species are summarized in Table 6 . In the

TABLE 4. Maximum responses to intravenous injection of histamine and histamine concentration of lung of four animal species

Mean \pm S.F.M.

\begin{tabular}{|c|c|c|c|c|c|c|}
\hline & & & & \multirow{2}{*}{\multicolumn{2}{|c|}{ Aortic BP }} & \multirow{3}{*}{$\begin{array}{l}\text { Histamin } \\
\mu \mathrm{g} / \mathrm{g} \\
\text { lung }\end{array}$} \\
\hline \multirow{2}{*}{$\begin{array}{l}\text { Procedure. } \\
\text { Intravenous } \\
\text { injection of }\end{array}$} & \multirow{2}{*}{$\begin{array}{l}\text { No. and } \\
\text { species of } \\
\text { animals }\end{array}$} & \multicolumn{2}{|c|}{ Resistance* } & & & \\
\hline & & Control & $\%$ change & $\begin{array}{l}\text { Control, } \\
\mathrm{mm} \mathrm{Hg}\end{array}$ & $\%$ change & \\
\hline $\begin{array}{c}\text { Histamine } \\
5 \mu \mathrm{g}, \mathrm{kg} \\
\text { Histamine }\end{array}$ & 5 rabbits & $11 \cdot 5 \pm 1 \cdot 2$ & $+24 \pm 20$ & $85 \pm 15$ & $+5 \pm 5$ & $4 \cdot 86 \pm 1 \cdot 08$ \\
\hline $\begin{array}{r}\text { Histamine } \\
10 \mu \mathrm{g} \mathrm{kg} \\
\text { Histamine }\end{array}$ & 5 rats & $0.62 \pm 0.09$ & $+26 \pm 3$ & $73 \pm 8$ & $-8 \pm 6$ & $5 \cdot 00 \pm 0 \cdot 17$ \\
\hline $\begin{array}{c}\text { Histamine } \\
1 \mu \mathrm{g} / \mathrm{kg} \\
\text { Histamine }\end{array}$ & 5 cats & $27 \cdot 4 \pm 3 \cdot 2$ & $+26 \pm 5$ & $129 \pm 7$ & $-63 \pm 8$ & $12 \cdot 03 \pm 2 \cdot 27$ \\
\hline $1 \mu \mathrm{g} / \mathrm{kg}$ & 8 dogs & $7 \cdot 5 \pm 1 \cdot 0$ & $+27 \pm 10$ & $125 \pm 8$ & $-29 \pm 5$ & $27 \cdot 71 \pm 4 \cdot 50$ \\
\hline
\end{tabular}

TABLE 5. Content of biogenic amines in the lung of mice infected with chloroquine-resistant strain of Plasmodium berghei

\begin{tabular}{|c|c|c|c|c|c|c|}
\hline \multirow[b]{2}{*}{ Procedure } & \multirow{2}{*}{$\begin{array}{c}\text { No. of } \\
\text { ani- } \\
\text { mals }\end{array}$} & \multirow{2}{*}{$\begin{array}{c}\% \\
\text { Parasi- } \\
\text { taemia* }\end{array}$} & \multicolumn{4}{|c|}{ Mean \pm S.E.M. $\mu \mathrm{g} / \mathrm{g}$ lung } \\
\hline & & & & $5-\mathrm{H}$ & line & \\
\hline 1 mice & $\begin{array}{l}32 \\
32\end{array}$ & $\begin{array}{r}0 \pm 0 \\
25 \pm 4\end{array}$ & $\begin{array}{l}0.70 \pm 0.15 \\
1.60 \dagger \pm 0.21\end{array}$ & $\begin{array}{l}5.67 \pm 0.99 \\
0.42 \dagger \pm 0.07\end{array}$ & $\begin{array}{l}0.09 \pm 0.01 \\
0.07 \pm 0.01\end{array}$ & $\begin{array}{l}0.09 \pm 0.01 \\
0.11 \pm 0.03\end{array}$ \\
\hline
\end{tabular}

* Percentage of erythrocytes containing plasmodia in blood smear.

$+P<0.005$ difference from mean of control animals. 
mouse, guinea-pig and cat, the values obtained by the fluorimetric technique are lower than those based on biological assay of histamine. If the results obtained using the present technique are compared, the eight species can be divided into three groups: (a) the mouse lung, which contains the lowest amount of histamine, $0.70 \mu \mathrm{g} / \mathrm{g}$; (b) the rat, guinea-pig and rabbit lungs, with a histamine concentration ranging from 4 to $7 \mu \mathrm{g} / \mathrm{g}$; and (c) the cat, dog, goat and human lungs, with a histamine concentration of from 10 to $35 \mu \mathrm{g} / \mathrm{g}$. Two species in the high-histamine content group (cat and dog) and two in the medium group (rat and rabbit) were tested for responses to intravenous injection of histamine. The high-histamine content group responded to $1 \mu \mathrm{g} / \mathrm{kg}$, with an increase in pulmonary resistance, whereas the medium-histamine content group required 5 to $10 \mu \mathrm{g} / \mathrm{kg}$ to elicit a definite increase in pulmonary resistance. There is, therefore, an inverse relationship between the concentration of histamine in the lung and the dose that would effectively increase resistance by $25 \%$.

The administration of reserpine, 5-HT or 5-hydroxytryptophan, which influences the 5-HT content of the lungs, does not influence histamine content (Sadavongvivad, 1970 ; Aviado \& Sadavongvivad, 1970). Only two conditions were found to affect the concentration of histamine in the lung. These were anaphylaxis and malaria. The phenomenon of trapping platelets in the lung during anaphylaxis, originally reported by Waalkes \& Coburn (1959), was confirmed in the rabbit. The guinea-pig did not show an increase of histamine in anaphylaxis. In the same guinea-pig, in anaphylaxis, the 5-HT content of the lung was higher than in the control, although the difference was not statistically significant. Loading of the animals with 5-HT before anaphylaxis raised the concentration of 5-HT in the lung, and it was further significantly raised after anaphylaxis. This suggests that the trapping of platelets,

TABLE 6. Histamine content of mammalian lungs

\begin{tabular}{|c|c|c|c|}
\hline Animal & $\begin{array}{c}\text { Histamine } \\
\mu \mathrm{g} / \mathrm{g}\end{array}$ & $\begin{array}{l}\text { Method of } \\
\text { assay }\end{array}$ & Author \\
\hline Mouse & $\begin{array}{l}2 \cdot 0 \\
0 \cdot 70 \pm 0 \cdot 15\end{array}$ & $\begin{array}{l}\text { Bioassay } \\
\text { Fluorometric }\end{array}$ & $\begin{array}{l}\text { Parratt \& West (1957) } \\
\text { This article }\end{array}$ \\
\hline Rat & $\begin{array}{l}9 \cdot 0 \\
4 \cdot 3 \\
14 \cdot 6 \\
5 \cdot 0 \pm 0 \cdot 17\end{array}$ & $\begin{array}{l}\text { Bioassay } \\
\text { Bioassay } \\
\text { Fluorometric } \\
\text { Fluorometric }\end{array}$ & $\begin{array}{l}\text { Parratt \& West (1957) } \\
\text { Agarwal, Deshmankar \& } \\
\text { Bhargava (1963) } \\
\text { Hauge \& Melmon (1968) } \\
\text { This article }\end{array}$ \\
\hline Guinea-pig & $\begin{array}{l}40 \cdot 0 \\
17 \cdot 5 \pm 54 \cdot 2 \\
7 \cdot 16 \pm 0 \cdot 83\end{array}$ & $\begin{array}{l}\text { Bioassay } \\
\text { Bioassay } \\
\text { Fluorometric }\end{array}$ & $\begin{array}{l}\text { Parratt \& West (1957) } \\
\text { Mota \& Vugman (1956) } \\
\text { This article }\end{array}$ \\
\hline Rabbit & $\begin{array}{l}2 \cdot 1 \\
4 \cdot 86 \pm 1 \cdot 08\end{array}$ & $\begin{array}{l}\text { Colorimetric } \\
\text { Fluorometric }\end{array}$ & $\begin{array}{l}\text { Graham, Hannergan \& Nourse } \\
\text { (1956) } \\
\text { This article }\end{array}$ \\
\hline Cat & $\begin{array}{l}29 \cdot 0 \\
34 \cdot 0 \\
12 \cdot 03 \pm 2 \cdot 27\end{array}$ & $\begin{array}{l}\text { Fluorometric } \\
\text { Bioassay } \\
\text { Fluorometric }\end{array}$ & $\begin{array}{l}\text { Colebatch \& DeKock (1963) } \\
\text { Parratt \& West (1957) } \\
\text { This article }\end{array}$ \\
\hline Dog & $\begin{array}{l}30-60 \\
25 \\
27 \cdot 7 \pm 4 \cdot 50\end{array}$ & $\begin{array}{l}\text { Bioassay } \\
\text { Bioassay } \\
\text { Fluorometric }\end{array}$ & $\begin{array}{l}\text { Aviado (1959) } \\
\text { Parratt \& West (1957) } \\
\text { This article }\end{array}$ \\
\hline Goat & $35 \cdot 44 \pm 5 \cdot 72$ & Fluorometric & $\begin{array}{l}\text { Aviado \& Sadavongvivad } \\
\quad(1970)\end{array}$ \\
\hline Human & $\begin{array}{c}6-25 \\
14 \cdot 12 \pm 4 \cdot 65\end{array}$ & $\begin{array}{l}\text { Bioassay } \\
\text { Fluorometric }\end{array}$ & $\begin{array}{l}\text { Riley \& West (1953) } \\
\text { Aviado \& Sadavongvivad (1970) }\end{array}$ \\
\hline
\end{tabular}


which is seen in rabbit anaphylaxis, also occurs in guinea-pig anaphylaxis. This can overshadow any release of the amine from the storage sites in the lung, so that analysis of the lung alone may not indicate any release of 5-HT.

The rise in the concentration of histamine in the lung of the mouse with malaria is a notable effect. It is accompanied by a fall in the 5-HT, so that the situation is different from anaphylaxis, in which one or both amines are elevated. A concomitant fall in the 5-HT concentration was explained by the ability of the parasite to metabolize 5-HT (Sadavongvivad \& Aviado, 1969). The rise in histamine may be due to an increase in the mast cell population or to the accumulation of basophils in the lung, which may contain high concentrations of histamine (Graham, Lowry, Wheelwright, Lenz \& Parish, 1955). A second explanation is that in situations characterized by rapid proliferation of cells-for example, in wound healing or neoplasia-the histidine decarboxylase activity increases. There may also be an increase in decarboxylase activity because of the rapid proliferation of parasites. A third interpretation of this increase of histamine in the lungs of malarial mice is found in the theory of inducible histamine formation, proposed by Schayer (1966). The inducible enzyme of Schayer is that increase in histidine decarboxylase activity which cannot be related to the development of new cells. An increase in histamine formation is found in situations such as local irritation, trauma, after a lethal dose of endotoxin and infection. Malarial infection may be another situation that causes an increase of histamine formation in the lung. It has not been possible to identify which one of these possibilities is the most important cause of the increase of histamine content of the lung of the malarial mouse.

This work was supported by a grant from the Council for Tobacco Research, New York City. This publication is based in part upon the thesis submitted by C. Sadavongvivad in fulfilment of the requirements for the degree of Doctor of Philosophy in Pharmacology, University of Pennsylvania.

\section{REFERENCES}

Agarwal, S. L., Deshmankar, B. S. \& Bhargava, A. (1963). Chloroquine in bronchial asthma. J. Pharm. Pharmac., 15, 693-696.

Aviado, D. M. (1959). Therapy of experimental pulmonary edema in the dog with special reference to burns of the respiratory tract. Circulation Res., 7, 1018-1030.

Aviado, D. M. (1967). Pathologic physiology and chemotherapy of Plasmodium berghei.: I. Suppression of parasitemia by sulfones and sulfonamides in mice. Expl. Parasit., 20, 88-97.

Aviado, D. M. \& Sadavongvivad, C. (1970). Pharmacological significance of biogenic amines in the lungs: Noradrenaline and dopamine. Br. J. Pharmac., 38, 374-385.

Aviado, D. M., SamaneK, M. \& Folle, L. E. (1966). Cardiopulmonary effects of tobacco and related substances. Arch. envir. Hlth, 12, 705-724.

Bartosch, R., Feldberg, W. \& NAGel, E. (1932). Das Freiwerden eines histaminähnlichen Stoffes bei der Anaphylaxie des Meerschweinchens. Pflügers Arch. ges. Physiol., 230, 129-132.

Carrillo, L. R. \& Aviado, D. M. (1968). Mechanisms for the bronchodilator effects of corticosteroids in the sensitized rabbit. J. Pharmac. exp. Ther., 164, 302-311.

Colebatch, H. J. H. \& DeKock, M. A. (1963). Histamine release in embolism of the lung with barium sulphate. Fedn Proc., 22, 282.

Dale, H. H. (1929). On some chemical factors in the control of circulation. Croonian Lectures, II and III. Lancet, 216, 1233-1237.

Engelhardt, G. \& Schwabe, U. (1960). Uber eine 5-hydroxytryptamin-Freisetzung unter der anaphylaktischen Reaktion des Meerschweinchens. Arch. exp. Path. Pharmak., 239, 170-183.

Graham, H. T., Hannergan, T. W. \& Nourse, C. M. (1956). Dependence of tissue histamine content on local histidine decarboxylase activity. Biochim. biophys. Acta, 20, 243-250.

Graham, H. T., Lowry, O. H., Wheelwright, F., Lenz, M. A. \& Parish, H. H. (1955). Distribution of histamine among leucocytes and platelets. Blood, 10, 467-477.

Hauge, A. \& Melmon, K. L. (1968). Role of histamine in hypoxic pulmonary hypertension in the rat. II. Depletion of histamine, serotonin, and catecholamines. Circulation Res., 22, 385392. 
Klide, A. M. \& Aviado, D. M. (1967). Mechanism for the reduction in pulmonary resistance induced by halothane. J. Pharmac. exp. Ther., 158, 1967.

Mariani, L. \& Valzelli, L. In Garattini, S., and Valzelli, L. (1958). Serotonin, p. 108. Amsterdam: Elsevier.

MoтA, I. (1966). Release of histamine from mast cells. In Handbook of Experimental Pharmacology, Vol. 18, pp. 569-635. Berlin: Springer Verlag.

Mota, I. \& Vugman, I. (1956). Action of compound 48/80 on the mast cells and histamine content of guinea-pig tissues. Br. J. Pharmac. Chemother., 11, 304-307.

Parratt, J. R. \& WeSt, G. B. (1957). Release of 5-hydroxytryptamine and histamine from tissues of the rat. J. Physiol., Lond., 137, 179-192, 1957.

Riley, J. F. \& WeSt, G. B. (1953). The presence of histamine in tissue mast cells. J. Physiol., Lond., 120, 528-537.

Rocha E Silva, M. (1966). Release of histamine in anaphylaxis. In Handbook of Experimental Pharmacology, Vol. 18, part I, pp. 431-480. Berlin: Springer Verlag.

SadavongVivad, C. (1970). Pharmacological significance of biogenic amines in the lungs: 5-hydroxytryptamine. Br. J. Pharmac., 38, 353-365.

Sadavongvivad, C. \& Aviado, D. M. (1969). Pathologic physiology and chemotherapy of Plasmodium berghei.: Mechanical properties and histological features of the lung. Expl. Parasit., 24, 313-326.

SCHAYER, R. W. (1966). Enzymatic formation of histamine from histidine. In Handbook of Experimental Pharmacology, Vol. 18, pp. 688-725. Berlin: Springer Verlag.

WAALKES, T. P. \& CoBURN, H. (1959). The role of platelets and the release of serotonin and histamine during anaphylaxis in the rabbit. J. Allergy, 30, 394-407.

(Received July 4, 1969) 